\title{
The Making of Salty Soy Sauce From Koro Benguk (Mucuna Pruriens) (Study of Saline Concentration of Salt Solution and Duration of Moromi's Fermentation)
}

\author{
Arie Febrianto Mulyadi, Wignyanto MS, Eka Yaniar Putri Nur Hidayah
}

Agroindustrial Technology Departement, Faculty of Agriculture Technology, Universtiy of Brawijaya, Indonesia A R T I C L E I N F O \begin{abstract}
A B S T R A C T
The objectives of this study were to determine the saline concentration and moromi's fermentation duration of Koro Benguk salty soy sauce at best organolepticly and determine consumers' preferences towards Koro Benguk salty soy sauce from the best treatment results. The study was conducted using a randomized design method using two factors: the saline concentration $(17 \% ; 20 \%$; and $23 \%)$ and duration of moromi's fermentation $(2 ; 3$; and 4 weeks). The best treatment results based on the Friedman test was on the saline concentration of $17 \%$ and moromi's fermentation duration was 4 weeks, with the NP value of 1,000; had a preference color level of 5:40 (liked); aroma of 4.30 (rather liked); flavor of 4.55 (rather liked); and viscosity of 5.05 (liked). The obtained protein was $7.14 \%$; and dissolved solids of $27^{\circ}$ brix. Consumers' preferences towards the best treatment showed that product of Koro Benguk salty soy sauce was acceptable to consumers.
\end{abstract}

Article history:

Received 24 June 2015

Accepted 22 December 2015

Available online, ISSN: 2148-127X

Keywords:

Moromi's Fermentation

Soy Sauce

Saline Concentration

Koro Benguk

"Corresponding Author:

E-mail: arie_febrianto@ub.ac.id

\section{Introduction}

Koro Benguk (Mucuna pruriens) is one of local pulses types which has different varieties and can be used as a substitute of raw material in the manufacture of tempeh (fermented soybean). Koro Benguk can also be processed into raw materials as an alternative of soy sauce. Soy sauce is a fermented liquid high protein materials from vegetables or animals in the saline solution. Soy sauce has dark brown color, distinctive smell, salty flavor and can make dishes tastier.

One of determining factors for quality of the product is the moromi's fermentation final result of soy sauce, because during the fermentation process the changes of microbiological and biochemical occured that affect the quality of fermentation end product (Grahita, 2008). According Koswara (1997) in Purwoko and Handajani (2007), basically the making of soy sauce through fermentation associated with the breakdown of proteins, fats, and carbohydrates into amino acids, fatty acids, and monosaccharides. The duration of moromi's soy sauce fermentation varies, i.e. for 3 weeks to 1 year (Isnawan, 2003). The longer duration of soy sauce fermentation, it will effect on the quality and effectiveness of the making of soy sauce (Kurniawan, 2008).

Determination of saline concentration in moromi's fermentation will also determine the quality of the soy sauce. The generally addition of salt to soy sauce is 20-
$23 \%$. The saline concentration used usually $17-19 \%$, and it will be dangerous if used at concentrations below $16 \%$, because it will cause decomposition and bacterial fermentation (lactic acid) will not be able to grow (Steinkraus, 1983 in Grahita, 2008). However the high saline concentration may result in death of microorganisms which should keep alive during moromi's fermentation. Therefore, salinity and time duration of moromi's fermentation is very important.

In this study, salty soy sauce made without the addition of seasoning, so it will be known the difference of soy sauce organoleptic and different time of fermentation. It is intended to obtain the salty soy sauce by organoleptic preferred by consumers. Therefore, consumers' preferences need to be conducted to determine whether the consumer like the product or not.

\section{Materials and Methods}

\section{Equipments and Materials}

Equipments used for the manufacture of Koro Benguk soy sauce were pan, stove, soaking container, fermentation tank, mixer, basin, digital scales (Denver Instrument M-310, China), measuring cups, knives, bottles, boiler, filter cloth, plastic and funnel. The equipments used for the analysis are the Kjeldahl flask 
(Buchi, Switzerland), Erlenmeyer (Merck, German), distillator (Merck, German), refractometer (Atago, USA).

The main ingredients used in this study were Koro Benguk and salt. Additional ingredients used for making Koro Benguk tempeh were flour and yeast. Materials used for analysing the proteins levels including $\mathrm{K}_{2} \mathrm{SO}_{4}, \mathrm{HgO}$, $\mathrm{H}_{2} \mathrm{SO}_{4}$, boiling stones, $\mathrm{H}_{2} \mathrm{BO}_{3}$, red methyl, $\mathrm{HCl}$, blue methylene, $\mathrm{NaOH}$, solution of boric acid.

\section{Experimental Design}

The experimental design used was a Randomized Block Design using two factors: Factor I was the time duration of fermentation with three levels, namely $\mathrm{Ti}=2$ weeks, $\mathrm{T}_{2}=3$ weeks, and $\mathrm{T}_{3}=4$ weeks. Factor II was the saline level with three levels, namely $\mathrm{P}_{1}=17 \%, \mathrm{P}_{2}=20 \%$, and $\mathrm{P}_{3}=23 \% \mathrm{w} / \mathrm{w}$.

\section{The Making of Koro Benguk Tempeh}

Koro Benguk was washed thoroughly, then boiled for 2 hours. After that peeled off the skin and split the seeds, then thoroughly washed and soaked for 48 hours in ratio of Koro Benguk to water was 1: 2. During the 48 hours of soaking, seeds of Koro Benguk were washed every 4-8 hours by washing it 3 times of each water changing. After 48 hours, Koro Benguk was washed and steamed for 1 hour starting from boiling water. Then drained and cooled. After Koro Benguk was cooled down, the tempeh yeast of $1 \%(\mathrm{w} / \mathrm{w})$ and wheat flour of $5 \%(\mathrm{w} / \mathrm{w})$ were added. Wheat flour used was roasted in advance, in order to eliminate microorganism. The addition of wheat flour was used as an addition to the nutrients and as a medium for mold growth. Then, it was inoculated for 4 days to make them into Koro Benguk tempeh.

\section{The Making of Salty Soy Sauce From Koro Benguk}

The making of soy sauce was done by weighing Koro Benguk tempeh of $200 \mathrm{~g}$, then chopped and dried until the moisture level was below 40\%. Once Koro Benguk tempeh was dried, Koro Benguk tempeh was inserted into a glass container and then fermented in saline solution for 2,3 , and 4 weeks. The container was covered with a filter cloth, and dried for 3-4 hours every day under the sun directly. The water used was $400 \%(\mathrm{v} / \mathrm{w})$ and saline concentration of $17 \%, 20 \%$, and $23 \%$ (w/w). Once fermented for 2, 3, and 4 weeks, soy sauce filtrate was obtained and then diluted before cooking. The ratio of the filtrate to water was $1: 1.5$. Then it was cooked for 30 minutes, then it was filtered and packaged.

\section{Organoleptic Test of Koro Benguk Salty Soy Sauce}

Organoleptic test of Koro Benguk salty soy sauce was done by organoleptic parameters include color, aroma, flavor, and viscosity, using 20 panelists. The data obtained was in the form of organoleptic test results which was processed using hedonic scale scoring method, expressed in a score of 1 (very disliked), 2 (disliked), 3 (somewhat disliked), 4 (neutral), 5 (rather liked), 6 (liked), 7 (really like) (Soekarto, 1985).

\section{Data Analysis}

Data of organoleptic result of Koro Benguk soy sauce will be analyzed using the Friedman test. If the Friedman test showed significant difference, then the test of Friedman's rank sum will be conducted. While to determine the best treatment of organoleptic data results of Koro Benguk soy sauce, the analysis of selecting the best treatment by using effectiveness index method was conducted (De Garmo et al. 1984). The best treatment results then will be analyzed its protein levels by Kjeldah method (Andarwulan et al. 2011), soluble solids by a refractometer (AOAC, 1995) and consumer preferences by using a preference test conducted on 20 panelists.

\section{Results and Discussion}

\section{Characterization of Koro Benguk Salty Soy Sauce}

Baseline characteristics of Koro Benguk before processing was known as big as a tip of the little finger in size which close to a square shape with white and black spots, black, and white in color. Seed of Koro Benguk contains acidic cyanide (HCN), which is toxic, so it needs to be soaked with clean water for 48 hours with water changes of every 4-8 hours by three times washing.

Organoleptic Results of Koro Benguk Salty Soy Sauce Color: A Friedman test results to the color of Koro Benguk salty soy sauce can be seen in Table 1 .

Table 1 showed the difference for some treatments. Treatments with saline concentration of $17 \%, 20 \%$ and $23 \%$ at 4 weeks fermentation duration significantly different from other treatments. This was due to the duration of moromi's fermentation, the longer the fermentation, the darker color of soy sauce will be.

Table 1 showed that the longer duration of moromi's fermentation, the color of soy sauce produced is more disliked by consumers. This can be seen in the treatment of fermentation duration of 4 weeks which shows the highest score of 5.40; 5.20; and 5.15. During moromi's fermentation, the color of soy sauce solution will change due to the color formed as a result of browning reaction between reducing sugars and amino groups of proteins (Astawan, 1991 in Septiani et al. 2004). According Dedin, et al. (2006), color formation occurred during moromi's fermentation of soy sauce and cooking process. During the cooking process, the formation of brown color occured due to nonenzymated browning reactions, namely Mailard reaction and caramelization. Described by Harrison and Dake (2005) in Sulistyawati (2012), that Maillard reaction of the carbonate group of glucose reacts with the amino group nucleophilic of a protein that produces a distinctive color (brown).

Table 1 also showed that the color of soy sauce with higher saline concentrations disliked by consumers. However, soy sauce on second and third week with saline concentration of $17 \%$ had decreased due to slightly sediment it was produced, so that the color produced less dark. Saline solution was used to extract the dissolved nitrogen compounds present in molds fermented material into saline solution (Septiani et al. 2004). 
Flavor: Friedman test results to the color preference of Koro Benguk soy sauce can be seen in Table 2 .

Table 2 showed the concentration of the saline solution and the duration of moromi's fermentation which affect the flavor of Koro Benguk soy sauce. Treatment with saline concentration of $20 \%$ and $23 \%$ at 4 weeks fermentation duration shows significant difference. This was due to the longer duration of moromi's fermentation that make the flavour of soy sauce more savory. According Winarno (1997) in Asmoro et al. (2013), taste and flavor of food influenced by several factors: chemical compounds, temperature, and interaction with other flavor components.

Table 2 showed the longer duration of moromi's fermentation, the flavor of soy sauce are more preferred by consumers. According Rosida et al. (2010), moromi's extract in the making of soy sauce containing peptides or proteins that have accumulated with vegetable fatty acids and sugar as a result of the activities of Aspergillus sp which gives a savory flavor in soy sauce. According Sokhib (1986) in Septiani et al. (2004), during moromi's fermentation Pediococcus halophillus Lactobacillus delbrueckii ferments sugar and amino acids into lactic acid, acetic acid and lactic acid and succinate acid. Lactic acid and succinate acid are the components which cause savory flavor of soy sauce.

Table 2 showed consumers' optimum scores to the saline solution concentration of $17 \%$ in fermentation duration of 4 weeks, at saline solution concentration of $20 \%$ and $23 \%$ the consumers' optimum scores were at third week. Saline solution was used to extract the dissolved nitrogen compounds present in the mold fermented soy into saline solution. Thus, produced soy sauce has a good flavor and aroma (Septiani et al. 2004).

Aroma: A Friedman test results to the color preference of soy sauce koro surly can be seen in Table 3 .

Table 3 showed the concentration of the saline solution and the duration of moromi's fermentation which affect the aroma of Koro Benguk soy sauce. According Soekarto (1985) in Mulyadi et al. (2014a), the aroma is a combination of taste and flavor. Treatment with saline concentration of $17 \%, 20 \%$ and $23 \%$ showed significant difference. The longer duration of moromi's fermentation which make aroma of soy sauce was more savory.

Table 3 showed the longer duration of moromi's fermentation, the aroma produced is more preferred by consumers. This was because at the time of moromi's fermentation, types of bacteria will grow and yeasts produce compounds that cause Koro Benguk has typical aroma. This reorganizing was an advanced decomposition of components by enzymes exist in microbes to form organic compounds. During moromi's fermentation, bacterial and yeast become active to produce sugars and organic acids which create flavor and aroma of the soy sauce (Yulinery and Napitupulu, 1993). However, there was a decrease in the concentration of saline solution treatment of $23 \%$ for 4 weeks. In this treatment score obtained was 3.40. This was due to alcohol and aromatic compounds produced by the yeast during moromi's fermentation have not grown yet.

Table 1 The mean scores on the panelists assessment of Koro Benguk soy sauce color at various treatments of saline concentrations and fermentation duration.

\begin{tabular}{c|ccc}
\hline Treatment & & & \\
\hline Saline Concentration (\%) & Fermentation Duration (week) & Mean Scores for color & Notation * \\
\hline 17 & 2 & 4.30 & $\mathrm{a}$ \\
20 & 2 & 4.40 & $\mathrm{a}$ \\
23 & 2 & 4.35 & $\mathrm{a}$ \\
17 & 3 & 4.55 & $\mathrm{a}$ \\
20 & 3 & 4.65 & $\mathrm{a}$ \\
23 & 3 & 4.50 & $\mathrm{a}$ \\
17 & 4 & 5.40 & $\mathrm{bc}$ \\
20 & 4 & 5.20 & $\mathrm{bc}$ \\
23 & 4 & 5.15 & $\mathrm{bc}$ \\
\hline
\end{tabular}

*Description: different notation showed different treatment

Table 2 The mean scores on the panelists assessment of Koro Benguk soy sauce flavor at various treatments of saline concentrations and fermentation duration.

\begin{tabular}{|c|c|c|c|}
\hline Treatment & & & \\
\hline Saline Concentration (\%) & Fermentation Duration (week) & Mean Scores for flavour & Notation * \\
\hline 17 & 2 & 3.05 & $\mathrm{a}$ \\
\hline 20 & 2 & 3.45 & a \\
\hline 23 & 2 & 4.55 & bc \\
\hline 17 & 3 & 3.00 & $\mathrm{a}$ \\
\hline 20 & 3 & 4.15 & $\mathrm{~b}$ \\
\hline 23 & 3 & 4.05 & $\mathrm{~b}$ \\
\hline 17 & 4 & 3.40 & $\mathrm{a}$ \\
\hline 20 & 4 & 4.25 & bc \\
\hline 23 & 4 & 4.10 & $\mathrm{~b}$ \\
\hline
\end{tabular}

*Description: different notation showed different treatment 
Table 3 Mean scores on the panelists assessment of Koro Benguk soy sauce aroma at various treatments of saline concentrations and fermentation duration.

\begin{tabular}{c|ccc}
\hline Treatment & & & \\
\hline Saline Concentration (\%) & Fermentation Duration (week) & Mean Scores for aroma & Notation *) \\
\hline 17 & 2 & 3.35 & $\mathrm{a}$ \\
20 & 2 & 3.90 & $\mathrm{a}$ \\
23 & 2 & 4.30 & $\mathrm{bc}$ \\
17 & 3 & 3.25 & $\mathrm{a}$ \\
20 & 3 & 3.90 & $\mathrm{~b}$ \\
23 & 3 & 4.15 & $\mathrm{~b}$ \\
17 & 4 & 3.75 & $\mathrm{a}$ \\
20 & 4 & 4.25 & $\mathrm{bc}$ \\
23 & 4 & 3.40 & $\mathrm{~b}$ \\
\hline
\end{tabular}

*Description: different notation showed different treatment

Table 3 also showed the higher saline concentration, the aroma of soy sauce was more preferred by consumers. However, at treatment of $20 \%$ saline concentration for 2 weeks the bacteria and yeasts needed had not been able to grow, so that the aroma produced are less liked by consumers. In the treatment of $23 \%$ saline solution concentration for 4 weeks was also decreased.

Viscosity: Friedman test results to preference of Koro Benguk soy sauce viscosity can be seen in Table 4.

Table 4 showed the concentration of saline solution and the duration of fermentation which affect the viscosity of Koro Benguk soy sauce. Treatment with $23 \%$ of saline concentration for 3 weeks of fermentation duration showed significant difference. This indicates that the longer duration of fermentation affects the viscosity of soy sauce produced. From Table 4 it also can be seen that saline concentration influences the graphic of mean scores significantly.

Table 4 showed the longer duration of moromi's fermentation, the viscosity of soy sauce increasingly preferred by consumers with a score of $5.05 ; 4.65$; and 5.00. Salty soy sauce has texture which is more dilute than sweet soy sauce. Viscosity of sweet and salty soy sauce was affected by the amount of coconut sugar added during the cooking process. Sugar added to salty soy sauce is fewer than added to sweet soy sauce. However, this Koro Benguk soy sauce was not added by seasoning and sugar during the cooking time, resulting in soy sauce with watery texture.

\section{The best treatment}

The best treatment was chosen by comparing the scores of the product of each treatment from the organoleptic parameters. Treatment with the highest scores of the product was the best treatment.

Based on the calculation of weighting for each parameter, the weight scores of flavor (0.33), color (0.29), aroma (0.22), and viscosity (0.17) were obtained. The data indicate that the flavor was a major factor in determining the consumer's decision. According Winarno (2004), the flavor of a food is one of the factors which determine consumer acceptance of a product.

The best and worst scores of the parameter represents the level of panelists' preferences. The best score for aroma was 4.30 which means neutral and the worst value was 3.25 which means rather disliked. The best score obtained for color was 5.40 which means rather liked and worst score was 4.30 which means neutral. For flavor the best score obtained was 4.55 which means neutral and the worst score was 3.00 which means rather disliked. For the viscosity, the best score obtained was 5.05 which means rather liked and worst score was 3.10 which means rather disliked.

Selection of the best treatment based on organoleptic parameter of $\mathrm{T}_{3} \mathrm{P}_{1}$ treatment with a concentration of $17 \%$ saline solution and fermentation duration of 4 weeks which have the highest score of the product of 1,000 .

\section{Comparison with the Quality Standard of Soy Sauce}

From the best treatment results of organoleptic test conducted by 20 semi trained panelists, subsequently chemical test was conducted including proteins level and dissolved solids. The best treatment results obtained by $\mathrm{T}_{3} \mathrm{P}_{1}$ treatment, i.e. the making of Koro Benguk salty soy sauce with saline concentration of $17 \%$ and fermentation duration of 4 weeks. Comparison of laboratory test results with SNI (Indonesian National Standard, 01-2593-1999) can be seen in Table 6 .

Table 6 showed the comparison of the quality of soy sauce with Koro Benguk salty soy sauce. The aroma and flavor of Koro Benguk salty soy sauce is normally typical.

This was according to the quality standards of soy sauce that is normally typical.

Levels of the protein produced from the best treatment $\left(\mathrm{T}_{3} \mathrm{P}_{1}\right)$ was equal to $7.14 \%$, which had met the conditions set out in SNI for soy sauce that is a minimum of $2.5 \%$. Level of protein in soy sauce was derived from the activity of enzymes produced by mold. These enzymes served to break down complex proteins into simpler proteins. The fermentation process in saline solution, enzymes produced in the mold fermentation process are still active (Rahayu et al. 2005). According Sutiyani et al. (2012), processing methods, especially when cooking the sauce is very influential on results obtained, less perfect processing will cause damage to the protein during cooking process. 
Table 4 The mean scores on the panelists assessment of Koro Benguk soy sauce viscosity at various treatments of saline concentrations and fermentation duration

\begin{tabular}{c|ccc}
\hline Treatment & & & \\
\hline Saline Concentration (\%) & Fermentation Duration (week) & Mean Scores for viscosity & Notation * \\
\hline 17 & 2 & 3.90 & $\mathrm{a}$ \\
20 & 2 & 4.35 & $\mathrm{~b}$ \\
23 & 2 & 5.05 & $\mathrm{c}$ \\
17 & 3 & 3.25 & $\mathrm{a}$ \\
20 & 3 & 4.55 & $\mathrm{bc}$ \\
23 & 3 & 4.65 & $\mathrm{c}$ \\
17 & 4 & 3.10 & $\mathrm{a}$ \\
20 & 4 & 4.36 & $\mathrm{~b}$ \\
23 & 4 & 5 & $\mathrm{c}$ \\
\hline
\end{tabular}

*Description: different notation showed different treatment

Table 5 Weighing

\begin{tabular}{c|cccc}
\hline Parameter & Weight & Best Score & Worst Score & Ratio \\
\hline Color & 0.29 & 5.40 & 4.30 & 1.10 \\
Flavor & 0.33 & 4.55 & 3.00 & 1.55 \\
Aroma & 0.22 & 4.30 & 3.25 & 1.05 \\
Viscosity & 0.17 & 5.05 & 3.10 & 1.95 \\
\hline
\end{tabular}

Table 6 Comparison wih Quality Standards of Soy Sauce

\begin{tabular}{l|lcc}
\hline & Parameter & Laboratorium Test Result & SNI (01-2593-1999) \\
\hline \multirow{2}{*}{1.} & a. Aroma & Typical & Typical \\
& b. Flavor & Typical & Typical \\
\hline 2. & Protein & $7.14 \%$ & Min.2.5\% \\
3. & Dissolved Solid & 27 brix & Min 10 brix \\
\hline
\end{tabular}

Dissolved solids in Koro Benguk soy sauce with concentration of $17 \%$ saline solution and the duration of fermentation for 4 weeks showed 27brix, while in terms of quality standards of soy sauce of minimum dissolved solids was 10brix. This may imply that the dissolved solids of Koro Benguk soy sauce have meet the quality standards. According Risvan (2009) in Kusumadewi (2011), dissolved solids is other solutes beside sucrose, such as chloride salts; and sulphate of potassium, sodium, and calcium which respond themselves as brix and counted as equivalent to sucrose, so it can be said that the dissolved solids may be smaller than the total value of sugar.

\section{Consumers' preferences}

After obtaining the best treatment, i.e. Koro Benguk salty soy sauce with a concentration of $17 \%$ saline solution and fermentation duration of 4 weeks, then the acceptance test (preference test) toward 20 panelists was conducted. According Winarno (1987) in Mulyadi et al. (2014b), one of the criteria that can be used to test whether an additional food formula is acceptable or not is by using acceptance test. The criteria of acceptance consisted of the percentage of respondents who declined should be less than $25 \%$.

From the results of consumer preferences test, it was obtained the number of respondents who liked Koro Benguk soy sauce with a concentration of $17 \%$ saline solution and fermentation duration of 4 weeks (scores given were 5, 6, and 7 respectively). The assessment was given in four aspects: color, aroma, flavor, and viscosity. Based on the preference percentages, it can be seen that respondents liked all attributes of Koro Benguk salty soy sauce tested. For the attributes of color, respondents who liked were 19 people, for aroma were 16 people, for flavor were 16 people, and for viscosity were 15 people.

\section{Conclusion}

The best treatment was obtained organolepticaly in Koro Benguk salty soy sauce with concentration of $17 \%$ saline solution and fermentation duration of 4 weeks. It had the color preference level at 5.40 (liked), the aroma of 4.30 (rather liked), the flavor of 4.55 (rather liked), and a viscosity of 5.05 (liked). While for the chemical test of the best treatment, it was obtained the protein level of $7.14 \%$, while the quality standard of soy sauce is $2.5 \%$ at minimum. Koro Benguk salty soy sauce had dissolved solids at 27 brix, while the quality standards of soy sauce is 10 brix at minimum.

Consumer preferences towards the best treatment of Koro Benguk salty soy sauce showed that the product was acceptable by the percentage of consumers' preferences color of $95 \%$, aroma of $80 \%$, flavor of $80 \%$ and viscosity of $75 \%$.

\section{References}

Andarwulan N, Kusnandar F, Herawati D. 2011. Analisis Pangan. Dian Rakyat. Jakarta. Volume 3. Halaman 65.

AOAC, 1995.Official Methods of Analysis of The Association of Analytical Chemists. AOAC Inc. Washington D.C. Page 70. 
Astawan M, Astawan MW. 1991. Teknologi Pengolahan Pangan Nabati Tepat Guna. Akademi Pressido, Jakarta.

De Garmo ED, Sullivan WG. Canada JR. 1984. Engineer Economy. Machmilon Publishing Company. New York. Vol. 2. Page 48.

Dedin FR, Wijaya CH, Apriyantono A, Zakaria FR. 2006. Karakteristik Melanoidin Kecap Manis dan Peranannya Sebagai Antioksidan. Jurnal Teknologi dan Industri Pangan.Volume XVII.Nomor 3. Halaman 41.

Grahita AW. 2008. Pengaruh Lama Fermentasi Maromi Terhadap Kualitas Filtrat Sebagai Bahan Baku Kecap. Skripsi.Fakultas Teknologi Pertanian. IPB. Bogor Vol. 1. Halaman 65.

Isnawan HH. 2003. Perubahan Mutu Kecap Produksi Skala Rumah Tangga Selama Tiga Bulan Penyimpanan. Jurnal Teknologi dan Industri Pangan.Volume XIV.Nomor 3. Halaman 45.

Koswara S. 1997. Mengenal makanan tradisional hasil olahan kedelai. Buletin Teknologi dan Industri Pangan 8 (2): 75-76.

Kurniawan R. 2008. Pengaruh Kosentrasi Larutan Garam dan Waktu Fermentasi Terhadap Kualitas Kecap Ikan Lele. Jurusan Teknik Kimia Fakultas Teknologi Industri Itenas Bandung. Jurnal Teknik kimia Vol.2, No.2:134.

Rahayu A, Suranto, Purwoko T. 2005. Analisis Karbohidrat, Protein, dan Lemak pada Pembuatan Kecap Lamtoro Gung (Leucaena leucocephala) Terfermentasi Aspergillus oryzae. Bioteknologi.Volume 2.Nomor 1.

Risvan 2009. Konsentrasi Ragi Terhadap TSS http://www.iptekindo.com. Tanggal akses 10 Januari 2014.
Rosida DF, CH W. 2013. Karakteristik Moromi dan Kecap Manis Serta Kajian Aktivitas Antioksidannya.Rekapangan, 4(2). Halaman 12.

Septiani Y, Purwoko T. Artini P. 2004. Kadar Karbohidrat, Lemak, dan Protein pada Kecap dari Tempe. Jurnal Bioteknologi. Volume 1.Nomor 2.

Soekarto ST. 1985. Penilaian Organoleptik untuk Industri Pangan dan Hasil Pertanian. Bhratara Karya Aksara. Jakarta. Vol. 1. Halaman 31.

Steinkraus KH. 1983. Handbook of Indigenous Fermented Foods. New York, NY: Marcel Dekker. 671 pages

Sukardi S, Wignyanto W, Purwaningsih I. 2012. Tempeh Inoculum Application Test of Rhizopus oryzae with Rice and Cassava Flour as Substrate at Sanan Tempeh Industries-Kodya Malang. Jurnal Teknologi Pertanian, 9(3). Halaman 32.

Sutiyani S, Wignyanto W, Sukardi S. 2012. Pemanfaatan Limbah Cair (Whey) Industri Tahu Menjadi Nata de Soya dan Kecap Berdasarkan Perbandingan Nilai Ekonomi Produksi. Jurnal Teknologi Pertanian, 4(2). Halaman 16.

Wignyanto W, Kumalaningsih S. 2013. Low Tannins and HCN of Lindur Fruit Flour Products as an Alternative Food.Jurnal Teknologi Pertanian, 13(3).

Winarno FG. 1987. Gizi dan Makanan. Jakarta: Pustaka Sinar Harapan. Volume 1.Halaman 25.

Winarno FG. 2004. Kimia Pangan dan Gizi. Gramedia. Jakarta. Volume 3. Halaman 20.

Yulinery T, Napitupulu RNR. 1993. Pemanfaatan Koro Benguk (Mucuna pruriens) sebagai Bahan Dasar Pembuatan Kecap dan Tauco. Balitbang Mikrobiologi. Puslitbang Biologi. LIPI. Volume 1. Halaman 43. 